Hydrol. Earth Syst. Sci., 13, 1427-1438, 2009

www.hydrol-earth-syst-sci.net/13/1427/2009/

(C) Author(s) 2009. This work is distributed under

the Creative Commons Attribution 3.0 License.

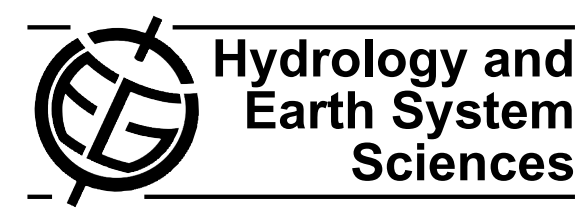

\title{
Future directions for hydropedology: quantifying impacts of global change on land use
}

\author{
M. J. Vepraskas, J. L. Heitman, and R. E. Austin \\ Department of Soil Science, North Carolina State University, Box 7619, Raleigh, NC 27695-7619, USA
}

Received: 29 January 2009 - Published in Hydrol. Earth Syst. Sci. Discuss.: 5 March 2009

Revised: 28 July 2009 - Accepted: 2 August 2009 - Published: 12 August 2009

\begin{abstract}
Hydropedology is well positioned to address contemporary issues resulting from climate change. We propose a six-step process by which digital, field-scale maps will be produced to show where climate change impacts will be greatest for two land uses: a) home sites using septic systems, and b) wetlands. State and federal laws have defined critical water table levels that can be used to determine where septic systems will function well or fail, and where wetlands are likely to occur. Hydrologic models along with historic rainfall and temperature data can be used to compute long records of water table data. However, it is difficult to extrapolate such data across land regions, because too little work has been done to test different ways for doing this reliably. The modeled water table data can be used to define soil drainage classes for individual mapping units, and the drainage classes used to extrapolate the data regionally using existing digital soil survey maps. Estimates of changes in precipitation and temperature can also be input into the models to compute changes to water table levels and drainage classes. To do this effectively, more work needs to be done on developing daily climate files from the monthly climate change predictions. Technology currently exists to use the NRCS Soil Survey Geographic (SSURGO) Database with hydrologic model predictions to develop maps within a GIS that show climate change impacts on septic system performance and wetland boundaries. By using these maps, planners will have the option to scale back development in sensitive areas, or simply monitor the water quality of these areas for pathogenic organisms. The calibrated models and prediction maps should
\end{abstract}

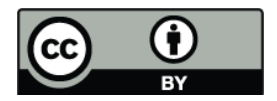

Correspondence to: M. J. Vepraskas (michael_vepraskas@ncsu.edu) be useful throughout the Coastal Plain region. Similar work for other climate-change and land-use issues can be a valuable contribution from hydropedologists.

\section{Introduction}

By uniting the disciplines of pedology and hydrology, hydropedology has created unique tools to address issues facing the environment. Hydropedology is well positioned to address contemporary problems that deal with land uses affected by saturated soil conditions, including some problems not currently recognized or addressed by scientists working in hydropedology. Our interest here is to explore ways in which hydropedology can be used to examine the impact that climate change may have on land use patterns. Climate change is currently an active area of investigation because of worldwide concern over the impacts it could have on land use. Public health impacts will be addressed indirectly by predicting where ground and surface water contamination may occur. Our focus will be on the Coastal Plain region of the Southeastern US. The methods we will explore can be used in any landscape with some modifications due to differences in soil conditions. Because we deal with future directions, our objective in this review is to propose a framework for evaluating the consequences of climate change on land use. We do not explicitly apply the method to obtain a final outcome, but instead identify potential problems that need to be addressed before the method can be fully realized.

Hydropedology tools and concepts will be very effective in addressing climate change issues, because they can be used to prepare spatially and temporally detailed maps that show

Published by Copernicus Publications on behalf of the European Geosciences Union. 
where and when the changes will occur (Fig. 1). County soil survey data are typically developed at scales of 1:24000 and can be used by hydropedolgists for areas as small as 1 ha. When portrayed at these map scales, the impacts of climate change can be seen and understood by landowners. A hypothetical example is shown in Fig. 1 for Pitt County, North Carolina, which is a rapidly growing area in the Southeastern US. The map shows where wetlands are expected to be found in the year 2050, and also shows where land is suitable for the septic systems that are commonly used for residential developments. With such information, county planners in 2009 can see where future housing developments should be placed, and where they should be prohibited to avoid creating a public health threat that results from septic systems that fail due to rising groundwater. Our goal in this review is to show how such maps might be prepared for counties across the Coastal Plain region by combining climate change predictions with soil survey data. We will use illustrations that were based on the assumption that global warming will cause water tables to rise. This assumption was used for convenience, and we emphasize that we do not know what the impacts of climate change will be at this time. However, the tools and concepts discussed will be applicable regardless of whether water tables over the next 30 years rise, fall, or remain where they are today.

\section{Proposed methods}

To achieve the objectives stated above, we propose a course of action that consists of six steps: 1) define land uses of interest, 2) define critical water table levels for each use, 3) estimate current water table levels in soils of interest, 4) extrapolate modeled water table data across broad geographic regions, 5) determine changes in water tables associated with climate change for future years of interest, and 6) create maps showing changes in potential land use patterns. We illustrate ways to achieve these steps by focusing on land use problems faced by planners in the Southeastern Coastal Plain.

\subsection{Land uses of interest}

The low lying Coastal Plain of the Southeastern US will be among the first land areas to experience potential impacts of climate change that affect sea level, precipitation, and temperature. This region extends from New Jersey southward along the coasts of the Atlantic Ocean and Gulf of Mexico to Texas, and is among the most rapidly developing areas in the US. While the region has historically been important for agriculture, since the 1970's the population has boomed, particularly around major cities such as Houston, Miami, Jacksonville, Charleston, and Virginia Beach among others (Lang and Dhavale, 2005). Most development has occurred in the suburbs around major cities.

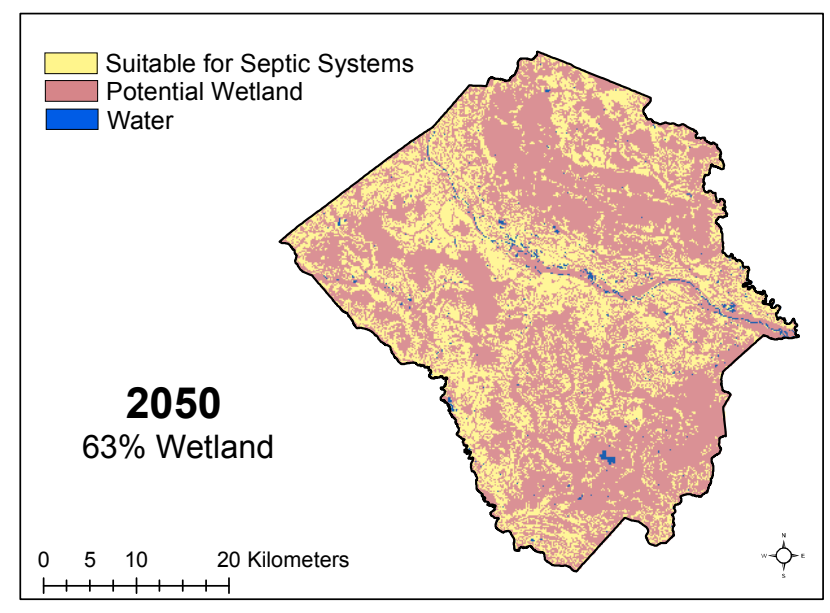

Fig. 1. A hypothetical illustration showing how soil mapping units can be used to portray suitable soils in one county in North Carolina for either septic systems or wetlands. In this example we've assumed that in 2050 over $60 \%$ of the soil mapping units will meet the requirements for jurisdictional wetlands.

How Coastal Plain soils are used is largely governed by the depth to their seasonal high water table (Daniels et al., 1999; Lindbo et al., 1998). As a result of the relatively flat topography, low elevation above sea level, and long distances between streams in the Coastal Plains, water tables can be found within $2 \mathrm{~m}$ of the surface in most Coastal Plain soils. Water table depth determines whether a given soil is either suitable for residential development and use of septic systems, or is capable of supporting freshwater wetland ecosystems. These land uses are important for consideration related to climate change because they are common in the Coastal Plain physiographic region of the Southeastern US, are affected by high water tables, and occupy mutually exclusive soils in a landscape.

Septic systems (Fig. 2), which depend on natural drainage and separation from the water table for waste treatment, are the major method of waste disposal in Southeastern suburban developments. According to census data (US Census Bureau, 2006), approximately 26 million households or $21 \%$ of the housing units in the United States use on-site systems for managing their household sewage. In North Carolina, almost one-half of the population relies on septic systems for domestic wastewater management (US Census Bureau, 1993). Based on the North Carolina population of 9061032 for 2007 (US Census Bureau, 2008) and the average number of people living in a household (2.5), we estimate the number of on-site wastewater treatment/disposal systems in the state to exceed 1.8 million. Assuming an average daily water use of $260 \mathrm{~L}$ per individual (EPA, 2002), and the aforementioned estimate of people currently using septic systems (4.5 million), the volume of wastewater applied daily to North Carolina soils through septic systems exceeds 1.17 billion L $\left(3.11 \times 10^{8}\right.$ gallons $)$. 
Approximately 50\% of the original wetland in the US had been drained or filled for agricultural or urban uses by the 1970's (Dahl, 1990). In North Carolina, drainage for agriculture has reduced wetland area from approximately $40 \%$ of the Coastal Plain prior to 1700 , to approximately $10 \%$ of the Coastal Plain in 1990's (Lilly, 1993). Expansion of suburbs has put increasing pressure on wetlands, but current state and federal laws are expected to maintain the existing wetland area (National Research Council, 1995). Existing laws require that before wetlands can be filled in or drained, permits must first be obtained from agencies such as the US Army Corps of Engineers. Such permits usually require that any lost wetland area be restored or replaced to offset the loss (National Research Council, 1995).

Climate changes that affect water table levels in soils will have major impacts on the use of soils and ultimately the interaction of residential development and wetlands. Development in Coastal Plain areas is determined to a large extent by the amount of land available for on-site waste disposal. On the other hand, jurisdictional wetlands often occur at locations where soils are unsuited for waste disposal. Because waste disposal and wetlands occur on mutually exclusive soils, we can simultaneously focus on defining the impact of climate change on both septic system performance and changes in wetland area. If land is suitable for a septic system, then it cannot be in a jurisdictional wetland according to current state and federal laws.

\subsection{Defining critical water table levels}

\subsubsection{Septic systems}

The most common type of septic system is the conventional or gravity fed septic system (Fig. 2). In general, a conventional septic system is composed of a septic tank and a drainfield. The drainfield is generally composed of a series of media-filled trenches that are approximately $90 \mathrm{~cm}$ wide and 60 to $90 \mathrm{~cm}$ deep, with a minimum of $270 \mathrm{~cm}$ distance between the centers of the neighboring trenches. For areas where the soils have limitations for a conventional system, an alternative system, such as low-pressure pipe distribution system (Cogger et al., 1988), areal fill (NCGA, 2005), or a drip system (Oron et al., 1991), are used for disposing of wastewater within the drainfield.

In order for a septic system to function properly, all the wastewater applied to the drainfield must infiltrate the soil and move vertically through the unsaturated (aerobic) soil below the trenches before entering a water table. In areas with relatively shallow water tables, maintaining an adequate thickness of aerobic-soil conditions between the bottom of the trenches and the seasonal high water table is crucial for proper treatment. Separation distance is the required distance between the bottom of drainfield trenches and the top of the seasonal high water table that is needed for proper treatment of wastewater by soil. This distance is specified by state

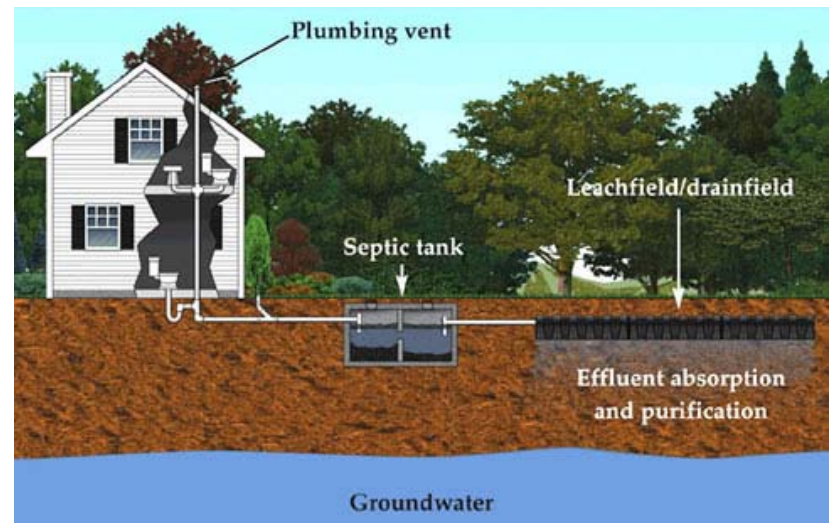

Fig. 2. An illustration of the components of a conventional septic system used for disposing of household waste in unsewered areas. These systems are widely used in suburban areas. Soil water table levels determine where such systems can be used, because the leachfield/drainfield must be a fixed distance above saturated soil layers in order for wastewater to seep into the soil and not come to the surface. (Drawing courtesy of Property Doctor, Johnson, RI).

laws, and in some states of the US this distance varies with soil texture. Cogger et al. (1988) conducted a field investigation in the Outer Banks of North Carolina and reported that more than $30 \mathrm{~cm}$ of separation distance between the bottom of the trenches and water table is required for removing $E s$ cherichia coli organisms from sandy soils with a high water table. In North Carolina, a minimum separation distance of $45 \mathrm{~cm}$ is required for sandy soils, but only $30 \mathrm{~cm}$ is required for all other soil textures (NCGA, 2005). Regulations differ slightly for other states. Regardless of the length of the separation distance, its purpose is to provide an aerobic environment for organic materials in the wastewater to be attenuated, and pathogenic microbes to be immobilized within the soil (Amador et al., 2006; Cogger, 1988; Powelson and Mills, 2001). Where site hydrology has been altered by drainage, separation distance is determined by monitoring water tables and rainfall (Lindbo et al., 2004; Severson et al., 2008). In North Carolina the seasonal high water table determined by monitoring is defined as the depth at which there is at least 14 days of continuous saturation for 3 out of 10 years (NCGA, 2005).

\subsubsection{Freshwater wetlands}

In the US, wetlands that are protected by state and federal laws are termed "jurisdictional wetlands". These wetlands are identified on the basis of three parameters: wetland hydrology, hydric soils, and hydrophytic plants (Environmental Laboratory, 1987). The most critical parameter is wetland hydrology (National Research Council, 1995), because it controls whether hydric soils can form and whether wetland plants will dominate the ecosystem. Hydric soils form under saturated and anaerobic conditions that occur during 
the growing season. Without saturation the soils will not become anaerobic, because water must fill enough pores in order to exclude atmospheric oxygen from the soil. Saturation is also necessary for hydrophytic plants to predominate (Conk and Fennessey, 2001).

Wetland hydrology can develop through either inundation (flooding or ponding) or by saturation with groundwater. Wetland soils on the Coastal Plain flats are not subject to flooding, but are saturated by groundwater when the water table is near but not necessarily above the surface. For jurisdictional purposes in the US, wetland hydrology occurs when soils are saturated within $30 \mathrm{~cm}$ of the surface for at least $5 \%$ of the growing season in at least 5 out of 10 years (Environmental Laboratory, 1987). Using this definition it is a simple matter to determine when wetland hydrology occurs at a site using a complete set of water table measurements that extend over a 10-year period. Vepraskas and Caldwell (2008) used DRAINMOD to model long-term $(40 \mathrm{yr})$ data sets of water table levels to identify sites in the NC Coastal Plain that met wetland hydrology conditions. They showed that sites with hydric soils met wetland hydrology conditions in over $85 \%$ of the years, and had hydrophytic vegetation as well.

\subsection{Predicting water table levels using hydrologic models}

Water table depths in soils can be predicted using hydrologic models such as DRAINMOD (Skaggs, 1978, 1999). DRAINMOD was originally developed to describe water table levels in drained agricultural fields. It is a functional, deterministic model based on a water balance in the soil profile, which is typically computed on an hourly basis for a long period of the climatological record. Input data include soil properties (e.g. saturated hydraulic conductivity, pore size distribution, depth to restricting layer, etc.), site and drainage system parameters, weather data, and parameters characterizing the crop or vegetation (He et al., 2002). The model determines water table depth and soil water content above the water table at each time step using functional algorithms and numerical methods to calculate infiltration, evapotranspiration, drainage, surface runoff, subirrigation, and deep and lateral seepage.

DRAINMOD can be used to simulate the hydrology of wetlands. Algorithms in the model are set to calculate the length of a continuous period when the water table is closer to the surface than a threshold depth. This calculation is conducted for the "growing season", which is a model input, and then analyzed to determine the presence or absence of wetland hydrology according to the jurisdictional definition. Skaggs et al. (1994) used this procedure to analyze proposed wetland hydrologic criterion (Skaggs et al., 1994). In addition, DRAINMOD has been field tested for a wide range of soils, crops, and climatological conditions (Skaggs, et al., 1981; Skaggs, 1982; Chang et al., 1983; Gayle et al., 1985; Rogers, 1985; Fouss et al., 1987; Broadhead and Skaggs,
1989; Cox et al., 1994; Karvonen and Skaggs, 1993). Results generally show that DRAINMOD reliably predicts water table fluctuations.

DRAINMOD was used by He et al. $(2002,2003)$ to predict water table fluctuations across a toposequence of Coastal Plain soils for a 40 -year period. The model was calibrated separately over a 2 to 3 year period by measuring daily water table levels and rainfall so that measured and predicted daily water table levels differed by an average absolute deviation of $<15 \mathrm{~cm}$. Model calibration was done separately for eight soil locations at two toposequences. A 40-year record of historic rainfall and temperature data (from the nearest available weather station) were input into each calibrated model to compute daily water table levels for each soil. Caldwell et al. (2007) used DRAINMOD to evaluate the 40-year water table levels of organic soils. Vepraskas and Caldwell (2008) used the data to determine the hydrologies of hydric soil field indicators that are used to identify wetland soils.

\subsection{Extrapolating modeled water table data across broad geographic regions}

While long-term water table data can now be estimated for virtually any soil with a locally-calibrated model, the data must be extrapolated to similar soils across broad geographic areas in order to portray climate-change impacts that will be of use to planners. Techniques for extrapolating such modeling results have not been tested to our knowledge. We propose that this can be accomplished using county soil-survey maps if water table data can be related to the mapping units. Soil mapping units are defined on the basis of a variety of soil properties. Each soil mapping unit has a soil taxonomic classification and soil drainage classification that are related to the soil's hydrology. A map unit frequently contains inclusions of other soils, and so most units cannot be assumed to be composed of a single kind of soil. The dominant soil in a mapping might be the most appropriate to use to extrapolate water table data to similar soils.

For this review, we will illustrate how soil drainage classes might be used in conjunction with soil maps to portray climate change impacts. Currently, the NRCS provides a drainage class for every soil series mapped, but the exact relationships to periods of seasonal saturation are not defined. Soils from common Coastal Plain toposequences in North Carolina will be used for this illustration.

\subsubsection{Toposequences and soil drainage classification}

The USDA's soil drainage classification system places any soil in one class on the basis of perceived depth to seasonal high water table during the wet months of a year of normal rainfall (Table 1). Five of the more common classes are shown in Table 1, but up to seven classes have been identified (Soil Survey Division Staff, 1993). As drainage class changes from well to very poorly drained, the seasonal high 
Table 1. Soil drainage class names, estimated depths to seasonal high water table, duration of ponding, suitability for on-site waste disposal, and likelihood of being found in a wetland (adapted from Soil Survey Division Staff, 1993).

\begin{tabular}{lllll}
\hline $\begin{array}{l}\text { Drainage } \\
\text { Class }\end{array}$ & $\begin{array}{l}\text { Estimated depth } \\
\text { to seasonal high } \\
\text { water table }(\mathrm{cm})\end{array}$ & $\begin{array}{l}\text { Duration of } \\
\text { water ponded } \\
\text { on surface }\end{array}$ & $\begin{array}{l}\text { Useable } \\
\text { for septic } \\
\text { systems }\end{array}$ & Wetland \\
\hline Well drained & $>120$ & None & Yes & No \\
Moderately well drained & $60-120$ & None & Yes & No \\
Somewhat poorly drained & $30-60$ & None & Yes & No \\
Poorly drained & $<30$ & Short (weekly) & No & Yes \\
Very poorly drained & $<30$ & Long (monthly) & No & Yes \\
\hline
\end{tabular}

water table rises closer to the surface, and duration of ponding on the surface increases as well (Fig. 3, Daniels et al., 1999). Hillslopes that contain soils with drainage classes ranging from well to poorly drained are called toposequences (Fig. 4).

As shown in Table 1, classifying soils by drainage class is useful for quickly assessing whether the soil is suitable for a septic system, or is in a jurisdictional wetland. Septic drainlines must be placed in soil at a depth that is above the depth of the estimated seasonal high water table. In the Coastal Plain, conventional septic systems are normally placed in soils having well or moderately well drainage classes. An alternative septic system can be placed in soils that are somewhat poorly drained. A variety of alternative systems are available to overcome the problems posed by soils with shallow water tables, such as installing drainlines above the soil surface in a mound of fill material (EPA, 2002). Poorly and very poorly drained soils are saturated too close to the surface to support any septic system that requires the use of the soil for waste disposal. As noted earlier, jurisdictional wetlands must be saturated at depths within $30 \mathrm{~cm}$ of the surface, or above the surface, for at least $5 \%$ of the growing season. This requirement can only be met in the poorly drained and very poorly drained soils.

Using the requirements discussed previously, water table data can be evaluated to determine if a soil is suitable for onsite waste disposal, or is in a jurisdictional wetland. Such water table data can also be used to place a soil in a particular drainage class. By assigning the drainage class to a soil mapping unit, the distribution of the soils suitable for a septic system, or that are likely in a jurisdictional wetland can be identified using existing county soil survey data.

\subsubsection{Toposequence types}

Most toposequences in the Coastal Plain region contain a similar range of drainage classes. Soils in Coastal Plain toposequences are distinguished primarily by their family particle size classification. The family particle size class is related to the textural classes of subsoil horizons (e.g. Bt and $\mathrm{C}$ horizons) over a carefully specified depth range (Soil Sur-

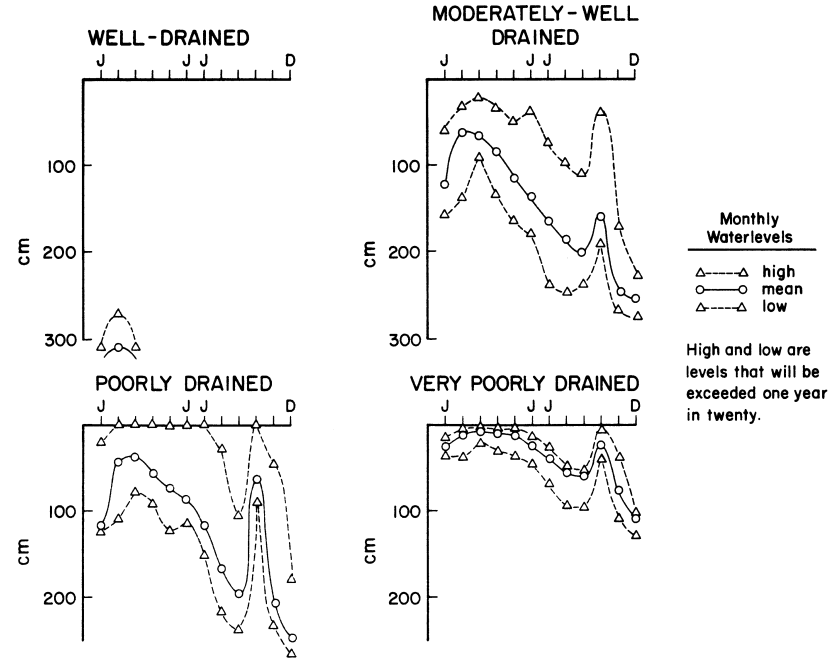

Fig. 3. Mean seasonal water table levels for four soil drainage classes. Data were obtained from Ultisols in the North Carolina Coastal Plain by Daniels et al. $(1987,1999)$ for the period 1963 through 1967 using the method of Nelson et al., 1973). Drainage classes offer a simple way of assessing soil suitability for septic systems, or identifying potential wetland areas. Long-term data (e.g. $40 \mathrm{yr}$ ) is desired to show the impacts of wet and dry years.

vey Staff, 1999). Each toposequence type will have soils in a particular textural class family. Names of soil series for common drainage classes in the NC Coastal Plain are shown in Table 2 for the dominant particle size classes (Daniels et al., 1999). Coastal Plain soils can be associated with a specific drainage classification as shown in Table 2, because each soil is found in a landscape position that determines the drainage class, and in fact drainage class characteristics (and particle size class) are used in the field to identify each soil.

It should be noted that while family particle size class differentiates many Coastal Plain toposequences from one another, this characteristic may be somewhat unique to this region. The soils across large portions of the Coastal Plain have similar mineralogy (kaolinitic), landscape characteristics, and sets of horizons. We are not suggesting that particle 
Table 2. Soil series found in common drainage classes in the Coastal Plain region in NC.

\begin{tabular}{|c|c|c|c|c|c|c|}
\hline \multirow[b]{2}{*}{$\begin{array}{l}\text { Textural } \\
\text { family name }\end{array}$} & \multirow{2}{*}{$\begin{array}{l}\text { Textures of } \\
\text { B or C } \\
\text { horizon }\end{array}$} & \multicolumn{5}{|c|}{ Drainage Class } \\
\hline & & Well & $\begin{array}{l}\text { Moderately } \\
\text { well }\end{array}$ & $\begin{array}{l}\text { Somewhat } \\
\text { poorly }\end{array}$ & Poorly & $\begin{array}{l}\text { Very } \\
\text { poorly }\end{array}$ \\
\hline Fine & $35-60 \%$ clay & Marlboro & Craven & Lenoir & Leaf & Bayboro \\
\hline $\begin{array}{l}\text { Fine-loamy } \\
\text { (siliceous mineralogy) } \\
\text { Fine-loamy }\end{array}$ & $18-35 \%$ clay (not silt loam) & Noboco & Goldsboro & Lynchburg & Rains & Pantego \\
\hline (mixed mineralogy) & $18-35 \%$ clay (not silt loam) & Wickham & Altavista & Augusta & Tomotley & Portsmouth \\
\hline Fine-silty & $18-35 \%$ (silt loam) & Aycock & Exum & Nahunta & Granthum & None described \\
\hline Sandy & Sand and loamy sand & Fripp & Corolla & Ousley & Osier & Murville \\
\hline
\end{tabular}

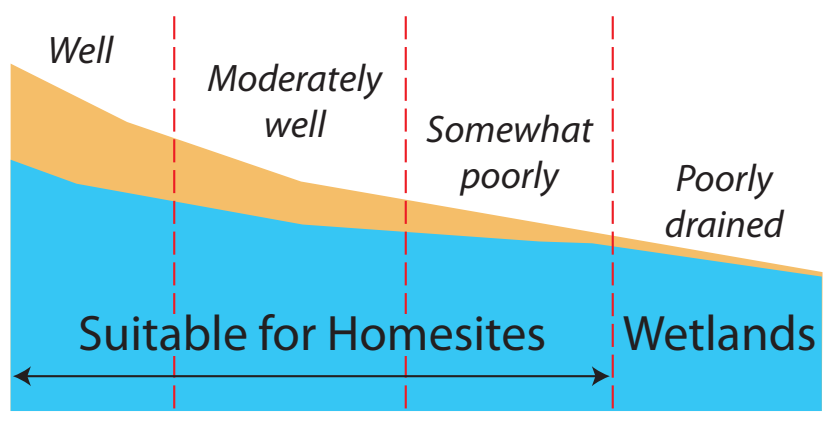

Fig. 4. Illustration showing changes in drainage class down a hillslope that forms a toposequence of soils. Soil used for septic system or wetlands are mutually exclusive. If a septic system is placed in a somewhat poorly drained soil it may function normally. However, if climate changes over the next 40 years and the somewhat poorly drained soil becomes poorly drained, then the septic system will fail, and the soil will be found in a jurisdictional wetland.

size class is the sole or major factor that differentiates toposequences from one another in all regions. Because of common mineralogy, soils in the same particle-size family for the Coastal Plain region have similar soil physical properties, such as pore size distribution and saturated hydraulic conductivity (Daniels et al., 1987, 1999). Hydrologic models describing water table dynamics of a Coastal Plain toposequence of soils in the same particle-size family should be more similar than in Coastal Plain toposequences that contain soils of other particle-size families. Their similar hydraulic conductivities and pore size distributions control soil drainage rate as well as degree of water table fluctuation for a given rainfall event. In other regions outside of the Coastal Plain, more soil properties may have to be considered when attempting to extrapolate hydrologic information.

In order to estimate water table levels in key soils of a single county, a hydrologic model will have to be calibrated separately for the two or three drainage classes of interest in a given toposequence. It is advisable to develop separate models for each drainage class of interest in each soil textu- ral class family. Drainage classes of interest will vary with the land uses of interest. For septic systems and wetlands, the most important drainage classes would be the somewhat poorly drained, poorly drained, and very poorly drained classes. At this time, we have to recommend that calibration studies be conducted in each of the particle-size families shown in Table 2 for Coastal Plain soils. It is not known at this point whether models developed for soils in a single drainage class for one particle-size family will be applicable to similar soils in other toposequences for that same family. Replicating calibration studies to develop models for the same soil type (drainage class and textural class) at different toposequences would also be advisable.

\subsubsection{Benchmark water table levels in soil drainage classes}

Once a calibrated model is available for a given soil type and drainage class, its benchmark water table signature can be determined (He et al., 2002, 2003). For this discussion we define a benchmark signature as the average water table level found for each day of a year over a 40-year period. A DRAINMOD model, or another modeling tool with similar capabilities, will compute water table levels over time from daily rainfall and temperature data. Long-term water table data must then be synthesized to produce simple parameters that can be used for analysis and related to land use. The parameters of interest will be determined by the objectives of the study. For this review, we obtain parameters shown in Table 3. The water table record for a given modeled soil will be used to determine each of the four hydrologic parameters of interest. The parameters in Table 3 were developed using current national regulations for wetland hydrology, or current state regulations governing on-site waste disposal in NC. A drainage classification will be assigned to each soil by using depth to low chroma soil colors, as is currently done by the USDA-NRCS. Hydrologic data will then be used to define the hydrologic signature for the drainage class found for each soil. 
Table 3. Hydrologic parameters that will be used to evaluate predicted water table data to evaluate whether soils are suitable for on-site waste disposal or are in wetlands. Drainage classes will also be defined with the data to allow assigning a drainage class to each soil should it have changed as a result of global warming.

\begin{tabular}{ll}
\hline Hydrologic Parameter of Interest & Definition of Hydrologic Parameter(s) \\
\hline 1. Proportion of years wetland hydrology conditions met & $\begin{array}{l}\text { No. of days water table within } 30 \mathrm{~cm} \text { of surface during } \\
\text { growing season. }\end{array}$ \\
$\begin{array}{l}\text { 2. Proportion of years site unsuitable for conventional } \\
\text { septic system }\end{array}$ & $\begin{array}{l}\text { within } 60 \mathrm{~cm} \text { of surface during winter months } \\
\text { 3. Proportion of years site unsuitable for alternative }\end{array}$ \\
$\begin{array}{l}\text { No. of 14-day-consecutive periods a water table is } \\
\text { within } 30 \mathrm{~cm} \text { of the surface during the winter months }\end{array}$ \\
$\begin{array}{l}\text { 4. Hydrologic signature for drainage class } \\
\text { areage depth of water table between months of November } \\
\text { through February } \\
\text { b. Average duration of ponding on soil surface between } \\
\text { months of November through February }\end{array}$ \\
\hline
\end{tabular}

\subsubsection{Problems to be resolved}

Methods for determining the extent to which results from a calibrated model can be extrapolated need to be developed. One potential approach to identify suitable soils for extrapolation would be to use the USDA-NRCS's online "Soil Series Classification Query Facility". To do this we would select a specific soil type for which a hydrologic simulation was developed (i.e., Lynchburg loamy sand). Similar soils can then be queried using, for example, 1) multiple MRLA's 2) suborder, 3) subgroup modifier 4) particle size family, 5) CEC activity, and 6) soil temperature regime. From these parameters (or potentially others) we can search the USDA database for appropriate soil mapping units to target for extrapolation of the modeled results. The criteria suggested above lead to several important connections between modeled units and extrapolation targets. Multiple MRLA's are specified to match the proper geologic conditions to those of the modeled soil. This not only can separate Piedmont from Coastal Plain soils, but also helps select soil parent materials of the appropriate age. Suborder and subgroup modifier will be used as proxies for soil drainage class. Particle size family and CEC activity are used because they are related to saturated hydraulic conductivity which is needed for modeling. Soil temperature is used because it is related to evapotranspiration.

\subsection{Determining future water table levels associated with climate change}

We propose that a hydrologic model such as DRAINMOD can be used along with predicted changes in rainfall and air temperature to determine water table dynamics under various climate-change scenarios. Data generated from the DRAINMOD predictions will provide the basis for identifying soils whose suitability of on-site waste disposal may be compromised, and where wetland areas are expanding. Data for fu- ture rainfall and temperature conditions, used to drive the hydrologic model(s), may be obtained from a number of available General Circulation Models (GCMs).

\subsubsection{Climate change affects on water tables}

Climate change directly affects precipitation amount and intensity, and potential evapotranspiration (Calder et al., 1995). Hydrologic models provide a framework for examining the complex effects of both climate and land use changes on watershed hydrology (Leavesley, 1994; Amatya et al., 1997; Arnold et al., 1999; Legesse et al., 2000; Arnold and Fohrer, 2005). For example, Stone et al. (2001) used the SWAT model (Arnold et al., 1999) coupled with a regional climate model to examine how doubling atmospheric $\mathrm{CO}_{2}$ affects water yield for the Missouri River Basin. They found that climate change may increase water yield in the fall and winter months but decrease it by 10 to $20 \%$ during spring and summer months. Similarly, using the SWAT model and six different climate change models, Jha et al. (2006) concluded that the Upper Mississippi River Basin was very sensitive to forecasted climate change scenarios. Few studies have been performed to examine climate change impacts for the Southeastern Region. McNulty et al. (1997) and Sun et al. (2000) studied change-climate impacts on forest hydrology at the watershed to regional scale across the Southern US using the ecosystem model PnET. They found that climate warming would increase forest evapotranspiration as forest growth increases, but overall water yield was expected to follow the trends of projected precipitation patterns. Using the DRAINMOD model, Amatya et al. (2006) examined climate change impacts on drainage and shallow groundwater table levels in a large, drained loblolly pine plantation on the lower coastal plain of eastern North Carolina. They concluded that climate change effects on drainage patterns are largely dependent on changes in precipitation. 


\subsubsection{Potential climate-change data sources and predictions}

The primary climate data needed to predict water table fluctuations (i.e., the future hydrologic regime) for soil toposequences via DRAINMOD are air temperature and rainfall. Amataya et al. (2006) used projected climate data from the VEMAP project (Kittel et al., 1997) to predict changes in drainage (i.e., water tables) for a 25-year window (20012025). Climate data from VEMAP were limited to two climate change-GCM scenarios, each giving distinctly different outcomes in terms of projected water table depths.

A robust set of predicted daily mean air temperature and rainfall intensity data are available by month through the year 2099 from the Lawrence Livermore National LaboratoryReclamation-Santa Clara University (LLNL-ReclamationSCU) downscaled climate projections data derived from the World Climate Research Programme's (WCRP's) Coupled Model Intercomparison Project phase 3 (CMIP3) multimodel dataset, stored and served at the LLNL Green Data Oasis (Meehl et al., 2007). CMIP3 includes 16 GCMs from various sources that allow comparative predictions of air temperature and rainfall intensity for three scenarios of greenhouse gas emissions (high emissions, moderate emissions with mixed sources, and clean, sustainable technology) from the IPCC (2000). Data provided from CIMP3 have been spatially downscaled to allow coverage of the contiguous US with a resolution of $1 / 8$ latitude-longitude $(\sim 12 \mathrm{~km}$ by $12 \mathrm{~km}$ ). However, work is needed before these data can be readily implemented in most current local hydrologic modeling tools (e.g. DRAINMOD). Different outcomes for temperature and rainfall intensity, and at each site, can be obtained depending on the modeling choice from the CIMP3 ensemble. An important component to using these data to drive hydrologic models is to characterize the uncertainty for each site across the suite of CIMP3 (or other) models.

Assuming appropriate climate data can be selected, climate change impacts on the four hydrologic parameters of interest can be computed for a given soil and its drainage class under new climate conditions. An example of data that might be obtained for one somewhat poorly drained soil is shown in Table 4. For this illustration, it can be seen that the soils in the somewhat poorly drained drainage class became wetter for the three climate change scenarios. Impacts for the Low $\mathrm{CO}_{2}$ scenario were minor, in that the soils did not meet wetland hydrology, and could still be used for onsite waste disposal. On the other hand, impacts for the High $\mathrm{CO}_{2}$ scenario were substantial. The soils did acquire wetland hydrology, were unsuitable for any septic system, and the hydrology signature is one that would be expected for very poorly drained soils. This analysis should be considered on both short (e.g. $10 \mathrm{yr}$ ) and long (e.g. 40 yr) timescales in order to identify trends in the hydrologic parameters under each climate scenario. Identification of temporal trends in the hydrology will permit isolation of soils that pose both immediate and long-term concerns for water quality impairment.

\subsubsection{Problems to be resolved}

Hydrologic Models such as DRAINMOD often require that predicted changes in precipitation and temperature be resolved into daily amounts of precipitation and temperature. Climate data for this short time step are not widely available, but could be derived using predicted changes from present conditions. Daily climate data collected at monitoring sites, that are used to calibrate the DRAINMOD model, provide a record of present climate conditions. These data can be aggregated to determine mean daily average temperature and rainfall intensity by month. Aggregate present conditions at the site would be analyzed versus larger time-step GCM data to determine the predicted year-to-year change in air temperature and rainfall intensity at each site throughout the period of interest. Predicted changes would then be translated into daily time steps by adjusting present climate records from the monitoring sites.

A second potential concern for developing climate inputs for hydrologic models with this approach is uncertainty in the frequency and magnitude of extreme weather events (i.e., prolonged dry periods or intense storms). These extreme events are commonly averaged over monthly time periods in GCMs, but may influence fluctuation in the water table via flooding or sustained water depletion from drought. It is anticipated that, because hydrologic signatures consistent with wetland conditions reflect sustained conditions, the magnitude of influence for individual events will be minimized. This is a research question in need of further evaluation.

\subsection{Creating maps showing changes in land use patterns}

For each soil of a toposequence, the predicted hydrologic data under a given climate change scenario (step 5) can be compared to the benchmark water table data (step 4) to determine if a soil's drainage class transitions into a more or less well drained class. Relating changes in soil hydrology to drainage class will enable us to use existing geospatial soils data (Soil Survey Staff, 2008a and b) to map where and when the changes in water table occur. To avoid extrapolating the model predictions to soil map units that are outside the range of the calibrated models, mapping units with similar taxonomic characteristics (e.g. drainage class, particle size family, temperature regime, mineralogy) will need to be aggregated and spatially analyzed as a common unit. By calibrating DRAINMOD to predict changes for each soil found within a toposequence, the maps should be able to predict across regions with similar toposequences as long as the soil physical properties fall within the range of the calibrated model. We propose that by using an existing soil survey and calibrated results from DRAINMOD we will be able to predict where and when changes in soil hydrology might occur. 
Table 4. Hypothetical example showing how the climate change predictions for three emission scenarios might be used with calibrated hydrologic models to determine the impact of climate change on water table levels. These data would pertain to a single soil mapping unit. Current conditions indicated that the unit would not be in a wetland, and might be suitable for an alternative septic system. If climate changes as a result of moderate $\mathrm{CO}_{2}$ levels, then the unit would become a wetland and any septic systems that had been placed in it would fail.

\begin{tabular}{|c|c|c|c|c|}
\hline \multirow[b]{2}{*}{ Hydrologic Parameter of Interest } & \multirow[b]{2}{*}{$\begin{array}{l}\text { Current } \\
\text { Conditions }\end{array}$} & \multicolumn{3}{|c|}{$\begin{array}{l}\text { Conditions following } \\
\text { climate change }\end{array}$} \\
\hline & & $\begin{array}{l}\text { Low } \\
\mathrm{CO}_{2}\end{array}$ & $\begin{array}{r}\text { Moderate } \\
\mathrm{CO}_{2}\end{array}$ & $\begin{array}{l}\mathrm{High} \\
\mathrm{CO}_{2}\end{array}$ \\
\hline $\begin{array}{l}\text { 1. Proportion of years wetland hydrology } \\
\text { conditions met }\end{array}$ & $0 \%$ & $0 \%$ & $50 \%$ & $80 \%$ \\
\hline $\begin{array}{l}\text { 2. Proportion of years site unsuitable for } \\
\text { conventional septic system }\end{array}$ & $60 \%$ & $70 \%$ & $80 \%$ & $95 \%$ \\
\hline $\begin{array}{l}\text { 3. Proportion of years site unsuitable for alternative } \\
\text { septic system }\end{array}$ & $10 \%$ & $15 \%$ & $30 \%$ & $50 \%$ \\
\hline $\begin{array}{l}\text { 4. Hydrologic signature for drainage class } \\
\text { a. Average depth of water table } \\
\text { b. Average duration of ponding }\end{array}$ & $\begin{array}{l}35 \mathrm{~cm} \\
0 \text { days }\end{array}$ & $\begin{array}{l}30 \mathrm{~cm} \\
0 \text { days }\end{array}$ & $\begin{array}{r}20 \mathrm{~cm} \\
10 \text { days }\end{array}$ & $\begin{array}{r}10 \mathrm{~cm} \\
40 \text { days }\end{array}$ \\
\hline
\end{tabular}

While this approach remains untested, the basic procedure for making land-use change maps is possible with existing soils data.

\subsubsection{Potential soils data sources}

The USDA Natural Resources Conservation Service (NRCS) develops, archives, and distributes soil data for the United States. At the most detailed level, soil data are distributed in the Soil Survey Geographic Database (SSURGO) format (Soil Survey Staff, NRCS, USDA, 2008a). The SSURGO database was (and continues to be) developed using national standards and standardized field and laboratory methods. The spatial data within the SSURGO database typically range in scale from 1:12000 to 1:64 000 and are the most detailed level of mapping performed by the NRCS (Soil Survey Staff, NRCS, USDA, 2008b). The SSURGO dataset contains georeferenced digital maps, computerized tabular attribute data, and associated metadata. SSURGO data are distributed by either county or survey area. Complete sets of spatial and tabular data are available for over $90 \%$ of the United States and for 98 of the 100 Counties in North Carolina. NRCS continually updates and maintains this data on local servers and makes the data available online through the Geospatial Data Gateway and the Soil Survey Data Mart.

A "map unit" within the SSURGO database represents a collection of associated soil series, with given surface texture, slope, etc. The map units are stored digitally as spatially referenced polygon features. Within a Geographic Information System (GIS), map units are linked to the descriptive tabular data by their map unit identifier and are typically used to develop maps and analyze soil properties. Many of the soil properties defined within the SSURGO database are deter- mined by physical factors and processes in the environment. As previously noted, a soil drainage class is determined by the estimated depth to the water table. As the depth to the water table decreases, the drainage class moves sequentially to a less well-drained class. Conversely, should depth to the water table increase, the drainage class transitions to a more well-drained class.

Using the DRAINMOD predictions for the benchmark water table signature, each soil mapping unit will be assigned a drainage class. At this time, we would use the dominant soil component for the map unit to assign a drainage class. The drainage class will then be used to determine whether the map unit is suitable for a septic system or is in a wetland. These results can be mapped using a GIS (Fig. 5a). A similar process can be used with the climate change data to identify map units that will change drainage class, and thereby change the types of uses they are suited for. By comparing the two maps within the GIS, areas where land use changes will occur can be portrayed (Fig. 5b). The maps produced provide planning tools at a variety of scales. At their most detailed, SSURGO data are appropriate to support assessments at county and watershed scales. Maps at these scales will help identify areas most suitable for future development, locations of greatest water quality risk from on-site waste system failure, agricultural areas most likely to increase or decrease in production, and locations of future wetlands or wetlands that might be at risk.

Illustration of the delineation of land use changes for Pitt County, NC is shown in Fig. 5. These spatial data were obtained from the United States Department of Agriculture (USDA), Natural Resources Conservation Service (NRCS). The map assumes that soils in the somewhat poorly drained drainage class have, as a result of climate change, 

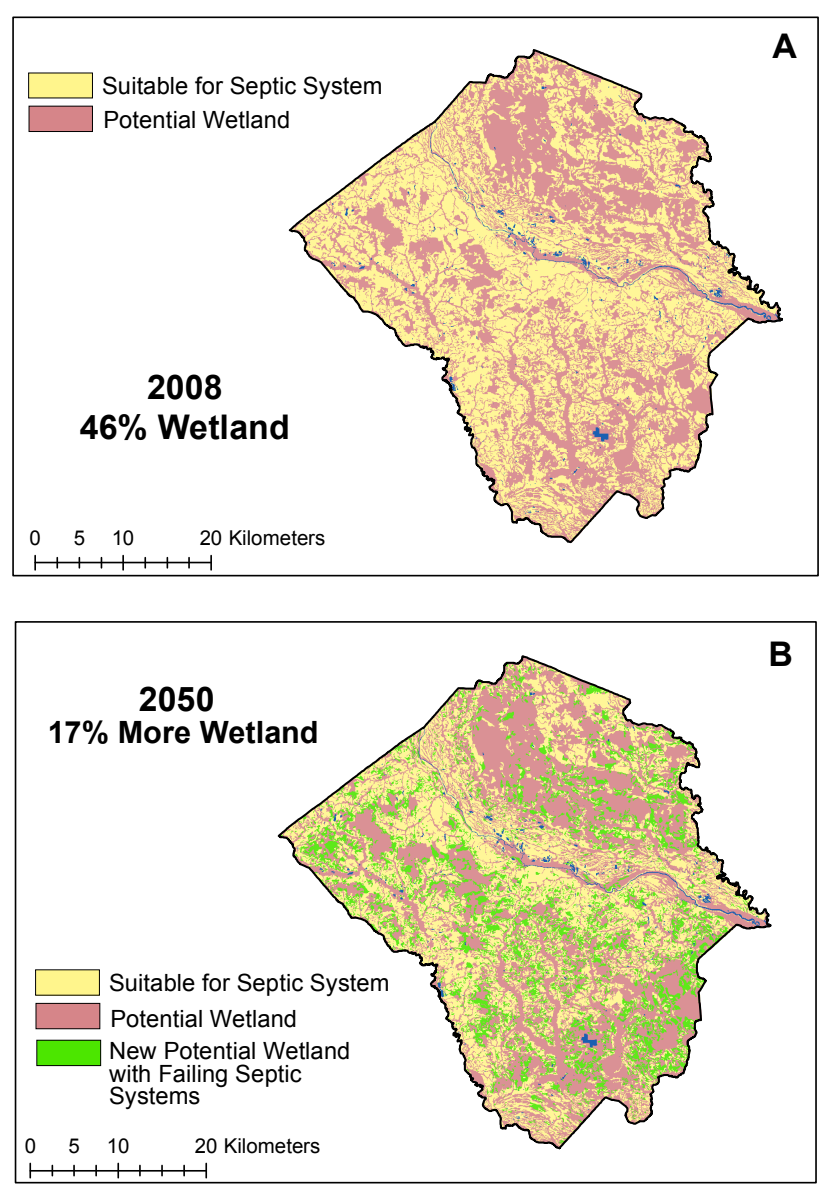

Fig. 5. County soil maps that have been adapted to show impacts of climate change on septic systems and wetlands in the years 2008 (A) and 2050 (B). GIS techniques were combined with the results from hydrologic modeling to identify areas where septic systems may fail as wetlands expand. The illustration is hypothetical and is used to show the type of product that might be produced. Such maps give land use planners an effective tool to identify areas that could be most affected by climate change.

transitioned to a poorly drained drainage class. The effect on potential land use is significant with an increase of wetland land area approaching $17 \%$ of the total land area. If these same soils had been previously been used for construction of septic systems, then rising water tables from climate change would cause any septic systems in these soils to fail, resulting in untreated sewage being brought to the surface, and possibly moving into surface water bodies. With maps as shown in Fig. 5, county planners can use several tools to prepare for possible climate change. At the very least, they could implement a monitoring program that requires inspection of septic systems in areas where failure is predicted. On the other hand, they may choose to restrict development entirely in the potentially affected areas.

\section{Summary}

Hydropedology is well positioned to address contemporary issues that affect public health and the environment that result from climate change. While other disciplines are evaluating climate change predictions on global scales, hydropedology provides tools that could allow us to show where climate change could impact land at county-level scales (i.e. 1:24000). Large scale maps can then be produced that show planners how climate change might directly impact landowners in their regions. Such maps will show landowners if their property is in an area that is at risk due to climate change.

To be able to develop such large-scale maps showing climate change impacts we have proposed a six-step process. Techniques are currently available to perform each of the six steps, however, more work needs to be done to improve the accuracy of the maps produced. We have identified where more work needs to be done. The issue that may be the most limiting to the entire process deals with extrapolating modeling results across large land areas. Currently too little work has been done on the topic for us to specifically identify the best approach. Nevertheless, the potential uses for such climate-change maps are so large, that these limitations should be viewed as critical challenges rather than insurmountable obstructions. The accuracy of such maps will depend not only on the climate change predictions, but also on how closely the soils in the map units match those that were used to calibrate the models. Nevertheless, we feel that the best way to convey the potential impacts of climate change to citizens will be through a visual portrayal of how climate change could affect them. Our intention has been to suggest one way that this could be done.

Edited by: H. Lin

\section{References}

Amador, J. A., Potts, D. A., Savin, M. C., Tomlinson, P., Gorres, J. H., and Nicosia, E. L.: Mesocosm-scale evaluation of faunal and microbial communities of aerated and unaerated leachfield soil, J. Environ. Qual., 35(4), 1160-1169, 2006.

Amayata, D. M., Skaggs, R. W., and Gregory, J. D.: Evaluation of a watershed scale forest hydrologic model, J. Agric. Water Manage., 32, 239-258, 1997.

Amataya, D. M., Sun, G. , Skaggs, R. W., Chescheir, G. M., and Nettles, J. E.: Hydrologic effects of global climate change on a large drained pine forest, in Proceedings of the Int. Conf. on Hydrol. and Management of Forested Wetlands, ASABE Publication No. 701P0406, 2006.

Arnold, J. G. and Fohrer, N.: SWAT2000: current capacities and research opportunities in applied watershed modeling, Hydrol. Process., 19, 563-572, 2005.

Arnold, J. G., Srinivasan, R., Muttiah, R. S., and Williams, J. R.: Large area hydrologic modeling and assessment - Part 1: model development, J. Am. Water Resour. As., 34, 73-89, 1999. 
Broadhead, R. G. and Skaggs, R. W.: A hydrologic model for artificially drained North Carolina peatlands, in: Agricultural Engineering, Proc. of the 11th International Congress, Dublin, edited by: Dodd, V. A. and Grace, P. M., 61-70, 4-8 September 1989.

Calder, I. R., Hall, R. L., Bastable, H. G., Gunston, H. M., Shela, O., Chirwa, A., and Kafundu, R.: The impact of land use change on water resources in sub-Saharan Africa: a modeling study of Lake Malawi, J. Hydrol., 170,123-135, 1995.

Caldwell, P. V., Vepraskas, M. J., Skaggs, R. W., and Gregory, J. D.: Simulating the hydrology of natural Carolina Bay wetlands, Wetlands, 27(4), 1112-1123, 2007.

Chang, A. C., Skaggs, R.W., Hermsmeier, L. F., and Johnson, W. R.: Evaluation of a water management model for irrigated agriculture, Trans. ASAE, 26(2), 412-418, 1983.

Cogger, C. G.: On-site septic systems: the risk of ground water contamination, J. Environ. Health, 51(1), 12-16, 1988.

Cogger, C. G., Hajjar, L. M., Moe, C. L., and Sobsey, M. D.: Septic system performance on a coastal barrier island, J. Environ. Qual., 17, 401-408, 1988.

Conk, J. K. and Fennessy, M. S.: Wetland plants: biology and ecology, Lewis Publ., Boca Raton, FL, 2001.

Cox, J. W., McFarlane, D. J., and Skaggs, R. W.: Field evaluation of DRAINMOD for predicting waterlogging intensity and drain performance in South-Western Australia, Aust. J. Soil Res., 32, 653-671, 1994.

Dahl, T. E.: Wetland Losses in the United States 1780s to 1980s, U.S. Dep. Interior, Fish Wildlife Serv., Washington, DC, USA, 1990.

Daniels, R. B., Gamble, E. E., Nelson, L. A., and Weaver, A.: Water-table levels in North Carolina soils, Soil Survey Investigations Rep. No. 40, USDA-Soil Conserv. Serv., U.S. Gov. Print. Off., Washington, DC, USA, 1987.

Daniels, R. B., Buol, S. W., Kleiss, H. J., and Ditzler, C. A.: Soil systems in North Carolina, Tech. Bull. 314. NC Agric. Research Serv., Raleigh, NC, USA, 1999.

Environmental Laboratory: U.S. Army Corps of Engineers wetlands delineation manual, U.S. Army Eng. Waterways Exper. Station, Tech. Rep. Y-87-1, Vicksburg, MS, USA, 1987.

Fouss, J. L., Bengston, R. L., and Carter, C. E.: Simulation subsurface drainage in the lower Mississippi Valley with DRAINMOD, Trans. ASAE, 30(6), 1679-1688, 1987.

Gayle, G. A., Skaggs, R. W., and Carter, C. E.: Evaluation of a water management model for a Louisiana sugar cane field, J. Am. Soc. Sugar-Cane Technol., 4, 18-28, 1985.

He, X., Vepraskas, M. J., Skaggs, R. W., and Lindbo, D. L.: Adapting a drainage model to simulate water table levels in Coastal Plain soils, Soil Sci. Soc. Am. J., 66, 1722-1731, 2002.

He, X., Vepraskas, M. J., Lindbo, D. L., and Skaggs, R. W.: A method to predict soil saturation frequency and duration from soil color, Soil Sci. Soc. Am. J., 67, 961-969, 2003.

Intergovernmental Panel on Climate Change (IPCC): Special Report on Emissions Scenarios, Cambridge University Press, UK, 570 pp., 2000.

Jha, M., Arnold, J. G., Grassman, P. W., Giorgi, F., and Gu, R. R.: Climate change sensitivity assessment on upper Mississippi basin streamflows using SWAT, J. Am. Water Resour. As., 42(4), 997-1016, 2006.

Karvonen, T. and Skaggs, R. W.: Comparison of different methods for computing drainage water quantity and quality, in: Trans.
Workshop on Subsurface Drainage Simulation Models, edited by: Lorre, E., 15th Int. Congress ICID, The Hague, 201-218, 1993.

Kittel, T. G. F., Royle, J. A., Daly, C., Rosenbloom, N. A., Gibson, W. P., Fisher, H. H., Schimel, D. S., Berliner, L. M., and VEMAP2 Participants: A gridded historical (1895-1993) bioclimate dataset for the conterminous United States, in: Proceedings of the 10th Conference on Applied Climatology, American Meteor. Soc., Boston, MA, USA, 219-222, 1997.

Lang, R. E. and Dhavale, D.: Beyond megalopolis: exploring America's new magapolitan geography, Census Report 05:01, Metropolitan Institute Census Report Series, Virginia Tech University, Blacksburg, USA, 2005.

Legesse, D., Vallet-Coulomb, C., and Gasse, F.: Hydrological response of a catchment to climate and land use change in tropical Africa: case study South Central Ethiopia, J. Hydrol., 275, 6785,2003

Leavesley, G. H., Markstrom, S. L., Restrepo, P. J., and Viger, R. J.: A modular approach to addressing models design, scale, and parameter estimation issues in distributed hydrological modeling, Hydrol. Process., 16(2), 173-187, 2002.

Lilly, J. P.: Wetland issues, SoilFacts no. 26, NC Cooperative Exten. Serv., AG-439-26, Raleigh, NC, USA, 1993.

Lindbo, D. L., Campbell, T. M., Deal, N., and Hollowell, R. P.: Performance of sand lined trench and conventional systems within a management entity, in: On-Site Wastewater Treatment. Proc., edited by: Sievers, D. M., Eighth National Symposium on Individual and Small Community Sewage Systems, 8-10 March, 1989, Orlando, FL, ASAE, St. Joseph, MI, 177-185, 1998.

Lindbo, D. L., Vepraskas, M. J., He, X., and Severson, E.: A comparison of soil wetness by morphological and modeling methods, in: On-Site Wastewater Treatment, edited by: Mancl, K., Proc. Tenth National Symposium on Individual and Small Community Sewage Systems, ASAE, St. Joseph, MI, 2004.

McNulty, S. G., Vose, J. M., and Swank, W. T.: Regional hydrologic response of southern Pine forests to potential air temperature and precipitation changes, Water Resour. Bull., 33, 10111022, 1997.

Meehl, G. A., Covey, C., Delworth, T., Latif, J., McAvaney, B., Mitchell, J. F. F., Stouffer, R. J., and Taylor, K. K.: The WCRP CMIP3 multimodel dataset: A new era in climate change research, B. Am. Meteorol. Soc., 88, 1383-1394, 2007.

National Research Council: Wetlands: characteristics and boundaries, National Academy Press, Washington, DC, USA, 1995.

Nelson, L. A., Daniels, R. B., and Gamble, E. E.: Generalizing water table data, Soil Sci. Soc. Am. J., 37, 74-78, 1973.

North Carolina General Assembly: Laws and rules for sewage treatment and disposal systems, North Carolina General Statute 130A-333,4, Rule 1900 of Title 15A Subchapter 18A of the North Carolina Administrative Code, Raleigh, NC, USA, 2005.

Oron, G., DeMalach, J., Hoffman, Z., and Cibotru, R.: Subsurface microirrigation with effluent, J. Irrig. Drain. E., 117, 25-36, 1991.

Powelson, D. K. and Mills, A. L.: Transport of Escherichia coli in sand columns with constant and changing water contents, J. Environ. Qual., 30(1), 238-245, 2001.

Rogers, J. S.: Water management model evaluation for shallow sandy soils, Trans. ASAE, 28(3), 785-790, 1985.

Severson, E. D., Lindbo, D. L., and Vepraskas, M. J.: Hydropedol- 
ogy of a coarse-loamy catena in the lower Coastal Plain, Catena, 73, 189-196, 2008.

Skaggs, R. W.: A water management model for shallow water table soils, Univ. NC, Water Resour. Res. Inst. Tech. Rep. 134, Raleigh, NC, USA, 1978.

Skaggs, R. W.: Field evaluation of a water management simulation model, Trans. ASAE, 25(3), 666-674, 1982.

Skaggs, R. W.: Drainage simulation models, in: Agricultural Drainage, edited by: Skaggs, R. W. and van Schilfgaarde, J., Agronomy Monograph No. 38, ASA, Madison, WI, 469-500, 1999.

Skaggs, R. W., Fausey, N. R., and Nolte, B. N.: Water management evaluation for North Central Ohio, Trans. ASAE, 24(4), 922928, 1981.

Skaggs, R. W., Amatya, D., Evans, R. O., and Parsons, J. E.: Characterization and evaluation of proposed hydrologic criteria for wetlands, J. Soil Water Conserv., 49, 501-510, 1994.

Soil Survey Division Staff: Soil survey manual, U.S. Dep. Agr. Handb. No. 18, U.S. Gov. Print. Off., Washington, DC, 1993.

Soil Survey Staff, Natural Resources Conservation Service, U.S. Dep. Agr.: Soil Survey Geographic (SSURGO) Database online available at: http://soildatamart.nrcs.usda.gov, accessed and verified 22 April 2008, 2008a.

Soil Survey Staff, Natural Resources Conservation Service, U.S. Dep. Agr.: Soil Survey Geographic (SSURGO) Database Description online available at: http://soils.usda.gov/survey/ geography/ssurgo/description.html, accessed and verified 22 April 2008, 2008b.

Soil Survey Staff: Soil taxonomy, 2nd edition, U.S. Dep. Agr. Handb. No. 436, U.S. Gov. Print. Off., Washington, DC, 1999.
Stone, M. C., Hotchkiss, R. H., Hubbard, C. M., Fontaine, T. A., Mearns, L. O., and Arnold, J. G.: Impacts of climate change on Missouri River Basin water yield, J. Am. Water Resour. As., 37(5), 1119-1129, 2001.

Sun, G., Amatya, D. M., McNulty, S. G., Skaggs, R. W., and Hughes, J. H.: Climate change impacts on the hydrology and productivity of a pine plantation, J. Am. Water Resour. As., 36(2), 367-374, 2000.

U.S. Census Bureau: 1990 Census of housing - Detailed housing characteristics, North Carolina, 1990 CH-2-35, U.S. Dept. of Commerce, Washington, DC, USA, 1993.

U.S. Census Bureau: American housing survey for the United States: 2005, 2006, online available at: http://www.census.gov/ prod/2006pubs/h150-05.pdf, accessed and verified on 29 April 2008, 2008a.

U.S. Census Bureau: National and state population estimates, 2008, online available at: http://www.census.gov/popest/states/ NST-ann-est.html, accessed and verified on 29 April 2008, 2008b.

U.S. Environmental Protection Agency: Onsite wastewater treatment systems manual, EPA/625/R-00/008, US Environmental Protection Agency, Office of Water, Washington, DC, USA, 2002.

Vepraskas, M. J. and Caldwell, P. V.: Interpreting morphological features in wetland soils with a hydrologic model, Catena, 73(2), 153-165, 2008.

Vepraskas, M. J., He, X., Lindbo, D. L., and Skaggs, R. W.: Predicting soil saturation frequency and duration using soil color in two toposequences, Soil Sci. Soc. Am. J., 68, 1461-1469, 2004. 